\title{
Principle of Legality and Its Relation with Customary Law in International Criminal Law
}

\author{
Abbas Barzegarzadeh ${ }^{1^{*}}$ \\ Mahmuod Jalali Karveh ${ }^{2}$ \\ Leila Raisi ${ }^{3}$ \\ ${ }^{1 * D e p a r t m e n t ~ o f ~ L a w, ~ I s f a h a n ~(K h o r a s g a n) ~ B r a n c h, ~ I s l a m i c ~ A z a d ~ U n i v e r s i t y, ~ I s f a h a n, ~ I r a n ~}$ \\ ${ }^{2}$ Department of Law, Faculty of Administrative Sciences and Economics, University of Isfahan, Isfahan, Iran \\ ${ }^{3}$ Department of Law, Shahrekord Branch, Islamic Azad University, Shahrekord, Iran \\ *Corresponding author: Abbas Barzegarzadeh, Email.: abbasbarzegar60@yahoo.com
}

Doi:10.5901/mjss.2015.v6n5p398

\section{Abstract}

Article 38 of the Statute of the International Court of Justice(ICJ) is considered to be the provider of a list of reliable sources for international law. Paragraph (1) (b) of the Article introduces customary law as the general practice of States members of the international community recognized as law(opinio juris). Therefore, each argument regarding customary international law as a main formal source, should be in line with the requirements of the mentioned Article. Although, before the Statute became binding, the concepts stated in this Article were already enforceable, the concepts may not have the same meaning in modern international criminal law whose main objective to prosecute and punish individual criminals committing humanitarian and human rights violations. The main objective of the present article is to demonstrate the extent the requirements of the establishment of custom in Article 38, i.e State practice and opinio juris, is applicable to criminal customary law. To do this the statutes of international criminal tribunals for former Yugoslavia(ICTY) and Rwanda(ICTR), human rights documents and the case law of the international criminal tribunals are examined. It seems that Article 38 of the Statute cannot be strictly applied to international customary law in criminal cases particularly when it comes to the application of the principle of legality or nullum crimen, nulla poena sine praevia lege poenali as a defence in criminal prosecutions.

Keywords: International Customary Law, Case Law, ICTY, ICTR, Principle of Legality

\section{Introduction}

Custom is comprised of some rules that regulate the everyday lives of people. These rules are formed by members of various social groups without necessarily knowing each other. At international level, custom is regarded as the second most important source. The present paper examines the judicial practice of two international criminal courts of ICTR and ICTY as well as international documents to figure out how customary law is developed in criminal matters(Nowak, 1993). They show that in application of the principle of legality to international criminal cases an expansive judicial interpretation and innovation has been taken.

\section{Statute of the International Criminal Court(ICC)}

The Statute of the ICC is a turning point in young history of international criminal law. The Statute was accepted in Rome in July 1998 and later became binding. Ratification of this Statute lead to development of customary law in this regard. It is regarded as an important step that may be completed more in future. The two under mentioned ad hoc international criminal courts too have played a particular role in preparing the mentioned laws(Meron, 2003).

\section{ICTR and ICTY Tribunals}

The ICTR and the ICTY case law supported the development of an international permanent criminal court. Their Statutes were influential in the studies done by special reporter of the International Law Commission(ILC), Professor Crawford, and the representatives who gathered to prepare the drafts for the Statute of the ICC in 1998. Article 21 of ICC Statute provides the Court shall apply:

(a) In the first place, this Statute, Elements of Crimes and its Rules of Procedure and Evidence; 
(b) In the second place, where appropriate, applicable treaties and the principles and rules of international law, including the established principles of the international law of armed conflict;

(c) Failing that, general principles of law derived by the Court from national laws of legal systems of the world including, as appropriate, the national laws of States that would normally exercise jurisdiction over the crime, provided that those principles are not inconsistent with this Statute and with international law and internationally recognized norms and standards (Bassiouni and Blakesley, 1992).

International lawmakers state that Article 21 has modified the approach taken by Statute of the ICJ so that it is reliable regarding international criminal law. Based on this interpretation, if an action is not considered as a crime according to the Statute but is considered as a crime according to general principles of international law, it will be tried in the ICC(Broomhall, 2003).

\section{Establishment of International Criminal Custom and the Principle of Legality}

This section examines the requirements and restrictions of the principle of legality regarding formation of new customary international law. The mentioned principle is regarded as an issue if the reasons for a customary norm are insufficient or the justification of a regulation is weak or a accused is tried and punished under these regulations and norms(Cryer, 2000).

The above-mentioned principle became very important when international criminal courts were being formed. The Secretary General of the United Nations stated that the international criminal court will execute international norms which are customary. The principle of legality includes various aspects regarding prohibition of retroactive, legal clarity and foreseeability of specific crimes (Carter, 1998).

The principle of legality exists in all legal systems of world. It can be seen in criminal law or in the private law and has its roots in the Roman school of thought. In its narrow sense, principle of legality means a series of criminal restrictions without legal basics. Interpretations of restrictions vary in different nations.

The above-mentioned is not directly referred to in the Statute of the International Military Tribunal at Nuremberg. It is regarded as a general principle of international law as stated in Article 38 (1) (c) of the ICJ Statute.

\section{Article 7 (1) of European Convention on Human Rights and Article 15(1) of Covenant on Civil and Political Rights}

The clause of legality of crimes in Article 7(1) of the European Convention on Human Rights and Article 15(1) of Covenant on Civil and Political Rights is similar to the restriction available in Article 11 of Universal Declaration of Human Rights. Based on Article 7(1) of European Convention on Human Rights, an action is regarded as crime if it is described as a crime by domestic or international law. These include written and customary law as stated in Article 38 of the ICJ Statute as well as general legal principles. Evaluation of Article 7(2) reveals that the entire Convention is made up of customary international law (Cassese, 2002).

\section{Article 7(3) of European Convention on Human Rights and Article 15 (2) of Covenant on Civil and Political Rights}

The exceptions to the principle of legality of crime in Article 7(2) of the European Convention on Human Rights and Article 15(2) of Covenant on Civil and Political Rights are very similar. Clause 2 of Article 7 of European Convention on Human rights and Article 15 of Covenant on Civil and Political Rights are found in the acknowledgement of the legitimacy of Nuremberg trials. The covenants should confirm that principles of international law that were formed in Nuremberg Statute are acknowledged by the majority of United Nations General Assembly(Davies, 1996).

\section{ILC Draft Code of Crimes Against the Peace and Security of Mankind and Legality Principle}

The interpretation of principle of legality was proposed by many documents of international human rights. It was formed as a set of regulations regarding crimes against peace and security of mankind by ILC. Though broad definition of law was criticized by members of the Commission, this solution was added to the final drafts. Then, members agreed that whether an action is a crime or not should be determined according to domestic or international law (Cassese et al, 2002).

The legality principles in international criminal law are different from their counterparts in national systems. They 
are unique because they should provide justice for the accused and take care of world order. This claim is acknowledged through considering the nature of international law, special processes of preparing drafts and fundamental assumption that international criminal norms are stated in domestic criminal law of various countries (Cassese, 2002).

Ambos claimed that changing a principle at the international level in order to turn it into a justice-oriented principle solely allows restrictions imposed by justice. First, the broad interpretation of a principle is associated to the definition of the corresponding law. Therefore, derivation of restrictions of an action or avoiding an action is allowed in terms of conventions, customs and principles (Bassiouni, 2008).

It seems that regarding legality principle, the interpretation of international law is broader compared to the interpretations in domestic laws. However, it is not completely proved whether this principle includes all specific restrictions(prohibition of retroactivity, legal clarity, prohibition of induction).

\section{Legality Principle in Positive Law and in Ad Hoc Criminal Courts}

The legality principle is more important where it comes to the situation when courts determine the issue of jurisdiction. When the ICTY was established the treaty laws were incomplete regarding the conflict situation in a country. So, this principle was of great importance. Therefore, the Secretary General of the United Nations emphasized on this issue regarding establishment of new courts. Secretary General of the United Nations stated that the ICTY should execute the existing customary humanitarian laws. This was not in the form of legislation. This principle played an important role regarding the issue of jurisdiction of the ICTR. Since the conditions regarding treaty laws were not complex, these actions were not emphasized (Higgins, 1994).

This principle was first discussed in the Tadic Appeal case. In this case, the appellant protested against legal establishment of the court and guarantee of fair trial based on documents on human rights. The Court stated that the phrases "established based on law" and "in accordance with legal regulations" should be interpreted based on their applications. Therefore, legality principle should be regarded as a fair principle. This principle is completely reliable at domestic level but cannot be easily generalized to the international level. The significance of this principle is more at the international level(Thouvenin, and Tomuschat, 2006).

\section{Specific Requirements of Legality Principle: Celebic Case}

The above mentioned verdict fully discusses the legality principle for the sake of development of international criminal law. People accused of violating Article 3 of the 1949 Geneva Conventions questioned the jurisdiction of the court based on principle of legality. The judges of the court stated that accusations include murder, torture and inhuman behaviors which are all considered as crimes in Bosnia and Herzegovina. Article 15(2) is also mentioned which states that these crimes should be tried in an international court. Also, the court emphasized that mentioning these issues in Article 15(2) is taken from experience of the Nuremberg and the Tokyo tribunals(Boister, 2002).

Consequently the judges of the court stated that these actions are considered as crimes based on regulations and norms known as general principles of international law which are also accepted by each legal system. The judges concluded that according to Article 15 (2) of Covenant on Civil and Political Rights, principle of legality is not violated(Kelsen, 1952).

Then, the judges of the court explain that clarity and avoiding ambiguity is an important issue in principle of legality which is accepted in all main legal systems of the world. Since the criminal justice systems are different in nature, it is not easy to implement this principle at international level. Before entering the international level, governments should consider some definite factors concerning this principle. Therefore, the judges of the court came up with this conclusion that accepting the principle of legality at the international level includes retroactive criminal law (Lahti, 1993).

Two issues should be accepted so that the principle of legality becomes clear. The first issue is that criminal law should be interpreted precisely. The second issue is that these principles should not be retroactive. The Celebic case reveals interesting aspects of the principle of legality at the international level. The judges of the above-mentioned case consider four aspects of the principle under international law: prohibition of international criminal law being retroactive, the principle of specificity, prohibition of analogy and rule of strict construction. Though the judges of the Court introduce different titles for them; it is believed that they are different parts of the principle of legality(Silek, 2001). Also, the court mentions special factors that should be regarded at the time of consideration of principle of legality in international criminal law. 


\section{Appeal of Hadzihasanovic}

The Court's findings reveal that the judges of the Appeal court do not discuss whether the responsibilities of mastery are enforceable in terms of domestic and international armed conflicts. An interesting aspect of ratified verdict is that the case reveals that it is able to response to the first issue regarding predictability principle through an inductive approach (Brownlie, 1998).

The case law of the ICTY which is going to be discussed here suffers from an ambiguity regarding legal clarity and principle of legality in customary international law. The judges proposed this question whether one who is a accused according to Article 3 was previously related to customary international law or not. The Court determined that accusation should be in accordance with customary international law and principle of legality. Also, the court stated that each punishment should be precise and achievable (Cassese et al, 2002).

The Court emphasized that its jurisdiction was based on customary international law. The judges concluded that drafts of ILC can solely be considered as the documents of regulations of international law. The regulations stated in the mentioned law reveal legal studies at the international level. They are not considered as components of a proper customary international law (Rosenne, 1998).

The Court repeated that each result regarding customary international law is the state of each specific crime which has to be in accordance with the principle of legality. The mentioned customary regulations should be interpreted precisely, the crime should be predictable and with logical results.

First, the court should convince the accused that the action or the set of actions committed constitute a crime according to customary international law. The judges of the court should also be convinced that the crime the person is accused of is evident according to customary international law and is predictable and executable as well. The judges of the court should consider the features of customary international law. A criminal crime should be defined in terms of principle of legality and should be evaluated so that it contains sufficient clarity (Blakesley, 1996).

The judges of the court claimed that restrictions of the principle of legality are implemented against formation of new international legal norms. It can be concluded that customary norms should have convincing clarity. It means these norms should be executable and predictable according to the accused. The drafts of crime laws of ILC cannot be regarded as the only reason in customary international law.

The jurisprudence of the ICTY reveals that the appeal court does disapprove some of the declarations of previous courts regarding the customary nature of specific crimes. According to the principle of legality, a crime should be sufficiently clear and predictable. Requirements of the principle of legality are not fulfilled solely because an action is hideous without being supported by State practice and opinio juris. Practice regarding "atomic law" reveal that an action being hideous may be sufficient as the customary reason of a specific regulation in international law. However, still proving opinio juris or State practice is needed (Sands, 2003).

\section{Cases before the ICTR}

The principle of legality made a great difference in positive law of the ICTR. The judges of the ICTR stated that: "Secretary General of the United Nations-in his report regarding establishment of ICTR-stated that it is proper for evaluating the principle of legality. This court should declare its stand regarding customary law or trial of accused according to international documents."

The recent decision of Karemera case confirmed that existence of specific norms is necessary at the time of commitment of a crime. These norms should be executable and predictable and should be in accordance with the ICTR constitution(Silek, 2001).

\section{Interpretation of the Principle of Legality by the ICTY and ICTR}

As revealed by the positive law of the two tribunals on the principle of legality, requirements for finding customary international criminal law is almost determined. Courts should respect the new customary regulations and norms regarding legal clarity and predictability. Of course, principle of retroactivity belongs to the same principle.

If we compare judicial practices of international courts regarding the principle of legality in terms of customary nature of international criminal courts, we will observe many differences. Laws imposed by ICTR are not always predictable or executable. Positive laws of the ICTY and the ICTR display the conflict between humanitarian aims and their precise interpretations. 


\section{Conclusion}

An examination of the principle of legality in human rights documents as well as in the case law of the ICTY and the ICTR, and in the ICC Statute, illustrate that the components of the principle can be considered as follows(Werle, and Jessberger, 2014): Prohibition of retroactivity; the rule of precise interpretation/strict construction which means transparency and foreseeability or the fact that the convicted understood that the behavior he/she was tried for was illegal. However, a survey of the international documents and of the jurisprudence of criminal tribunals, demonstrate that the modern international criminal law has failed to apply the traditional customary concept of the principle of legality and that the principle does not enjoy in international criminal law the same force and effect that it does in national legal orders.

As the criticisms regarding juridical practice of the ICTY reveal, "atomic law" approach is in conflict with principles of clarity and predictability. Also, emphasizing solely on "inductive approach" is against the idea of precise interpretation. If the inductive approach is taken without being supported by other reasons including State practice and opinio juris, may be contrary to the principle of legality. Therefore, components of traditional customary international law are also of great importance in terms of international criminal law.

\section{References}

Bassiouni, M. C., \& Blakesley, C. L. (1992). The Need for an International Criminal Court in the New International World Order. Vand. J. Transnat'l L., 25: 151.

Bassiouni, M. Ch. (2008). International Criminal Law: Sources, Subjects and Contents. Leiden, The Netherlands: Martinus Nijhoff Publishers.

Blakesley, C. L. (1996). Comparing the Ad Hoc Tribunal for Crimes against Humanitarian Law in the Former Yugoslavia \& the Project for an International Criminal Court, prepared by the International Law Commission. Revue Internationale de Droit Pénal, 67:139-208.

Boister, N. (2002). The ICJ in the Belgian Arrest Warrant Case: Arresting the Development of International Criminal Law. Journal of Conflict and Security Law, 7(2): 293-314. doi:10.1093/jcsI/7.2.293

Broomhall, B. (2003).International Justice and the International Criminal Court: Between Sovereignty and the Rule of Law. Oxford: Oxford University Press.

Brownlie, I. (1998). Principles of Public International Law. 5th ed. Oxford: Oxford University Press.

Carter, J. (1998). The statute of the international criminal court: a documentary history. New York: Transnational Publishers.

Cassese, A. (2002). When May Senior State Officials Be Tried for International Crimes? Some Comments on the Congo v. Belgium Case. European Journal of International Law, 13(4): 853-875. doi:10.1093/ejil/13.4.853

Cassese, A., Gaeta, P., \& Jones, J. R. (Eds.). (2002). The Rome Statute of the International Criminal Court: A Commentary (Vol. 1). Oxford: Oxford University Press.

Cryer, R. (2000). Commentary on the Rome Statute of the International Criminal Court. Journal of Conflict and Security Law, 5(2), 293294.

Davies, M. (1996). Delimiting the Law: postmodernism and the Politics of Law. London: Pluto Press

Higgins, R. (1994). Problems and process: international law and how we use it. Oxford: Oxford University Press.

Kelsen, H. (1952). Principles of international law. New Jersey: The Law book Exchange, Ltd.

Lahti , R. (1993). The Universal Declaration of Human Rights: A Commentary. Scandinavian University Press.

Meron, T. (2003). International law in the Age of Human Rights: General Course on Public International Law. Recueil Des Cours, Collected Courses, 301 (2007), 009-489. doi:10.1163/ej.9789004140202.009-489.1

Nowak, M. (1993). UN Covenant on Civil and Political Rights: CCPR commentary. NP Engel.

Rosenne. Sh. (1998). Some Reflections on Erga Omnes, in Antony Anghie and Garry Sturgess (eds.), Legal Visions of the 21st Century: Essays in Honour of Judge Christopher Weeramantry. The Hague: Kluwer Law International.

Sands, Ph. (2003). Principles of International Environmental Law. Cambridge: Cambridge University Press.

Silek, R. (2001). Otto Triffterer (ed.), Commentary on the Rome Statute of the International Criminal Court. Journal of International Peacekeeping, 7(1), 451-475. doi:10.1163/187541101×00309

Schlutter ,Brigit, developments in customary international law , koninklijke brill , leiden ( 2010)

Thouvenin, J. M., \& Tomuschat, C. (2006). The Fundamental Rules of the International Legal Order. doi:10.1163/ej.9789004149816.i472

Werle, G., \& Jessberger, F. (2014). Principles of International Criminal Law. Oxford University Press. 